\title{
Train station area gardens: the creation and evolution of Dr. José Esteves Square, in Lavras-MG ${ }^{(1)}$
}

\author{
IRACEMA CLARA ALVES LUZ ${ }^{(2) *}$, PATRÍCIA DUARTE DE OLIVEIRA PAIVA(2), \\ SCHIRLEY FÁTIMA NOGUEIRA DA SILVA CAVALCANTE ALVES ${ }^{(3)}$
}

\begin{abstract}
Studying the origins and transformations of a public square throughout time is extremely important, since it motivates its preservation and the consecration of its history. Therefore, the objective of this study was to carry out historic-cultural and landscape analyses of Dr. José Esteves Square and its whereabouts, built near a train station located in Lavras, Minas Gerais, Brazil. This research focused on the period between 1721 (settlement) and 2014. Dr. José Esteves Square was created to ornate and supports the arrival of passengers at the train station of Lavras. The way this public square was built is somewhat different from most public squares in Brazil, which are normally constructed around a church. Lack of maintenance, due to privatization, and the abandonment of train station facilities, made the gardens and areas around Dr. José Esteves Square lose their importance and the aesthetic characteristics they once had.
\end{abstract}

Keywords: historical gardens, landscaping, Minas Gerais, railroads, Estrada Real (Royal Road).

\section{RESUMO}

Jardins de áreas de Estação de Trem: a criação e evolução da Praça Dr. José Esteves em Lavras-MG

O estudo da origem e transformação de uma praça ao longo do tempo é de extrema importância, ocasionando a sua conservação e a consagração de sua história. Neste contexto objetivou-se realizar a análise histórico-cultural e paisagística da praça Dr. José Esteves e seu entorno, situada em Lavras MG, Brasil, originada próxima à estação ferroviária da cidade. A pesquisa centrou-se entre os anos 1721 (fundação do município) a 2014. A praça Dr. José Esteves foi criada com o intuito de ornar e dar apoio à chegada de passageiros pela Estação de Lavras. Sua formação ocorreu diferentemente da maioria das praças brasileiras, que normalmente tiveram sua construção relacionada a uma igreja. A falta de manutenção, associada à privatização e ao abandono dos prédios da ferrovia, fez com que seus jardins e adjacências perdessem a importância e as características estéticas que possuíam no passado.

Palavras-chave: jardins históricos, paisagismo, Minas Gerais, ferrovias, Estrada Real.

\section{INTRODUCTION}

Cultural and social manifestations, as well as other factors that are highly important for society and ingrained into the memory of the population, allow certain gardens and public squares to be regarded as historical, as mentioned in the Letter of Florence (CARTA DE FLORENÇA 1981): "A historical site is a defined area that remounts to a memorable fact: the location to a major historical occurrence, to the birth of a notorious myth or to an epic battle, issue of a famous event, etc.".

Nevertheless, within the reality in Brazil, public squares are equivalent to historical gardens when it comes to symbolic importance, since they are places where people meet and cohabit, just like public squares, gardens and footpaths in both historical towns and large cities (CARTA DE JUIZ DE FORA, 2010). Therefore, even if there are neither facts, nor highly important constructions, such places still have a historical value, once they may serve as a stage for daily life events, thus causing the population to be emotionally attached to their memories therefrom.

Gardens are subject to vicissitudes of time, due to the incorporation of organic materials, their exposure to all seasons, and historical shifts in taste and style (MORGAN, 2016), causing several alterations to their original traits. Therefore, rescuing the historical and landscape value of historical gardens is highly important for a society, for it brings up the awareness to preserve their heritage (ANDRÉ, 2008) and the desire to treasure such areas.

When Brazil was a colony of Portugal, the core of a village between the $16^{\text {th }}$ and the $19^{\text {th }}$ century used to be a chapel, around which there would be the first public open spaces in the country (JUSTE and PAIVA, 2015): these places used to be the stage to religious manifestations, such as christenings and processions, as well as civil, commercial, military and political acts (CALDEIRA, 2010), which originated the municipal public squares.

DOI: http://dx.doi.org/10.14295/oh.v23i4.1117

(1) Received in 19/08/2017 and accepted in 18/12/2017

(2) Universidade Federal de Lavras, Departamento de Agricultura, Lavras-MG, Brazil. *Corresponding author: iracemaaluz@gmail.com

${ }^{(3)}$ Centro Universitário de Lavras (UNILAVRAS), Lavras-MG, Brazil

Licensed by CC BY 4.0 
Historical gardens are found in many places throughout Brazil, especially along the cities and pathways opened by the so-called Royal Road (Estrada Real) in the State of Minas Gerais.

These cities grew throughout the Royal Road due to the exploration of gold during the Empire, since it was the path used to transport riches to the capital of the Empire, the city of Rio de Janeiro, during the $16^{\text {th }}, 17^{\text {th }}$ and $18^{\text {th }}$ centuries (MAGALHÃES, 2007). Such cities and municipalities would be founded by bandeirantes, a group of Portuguese settlers that went in expeditions throughout the countryside of Brazil (sertões), aiming at enslaving natives, seeking minerals and metals, and destroying settlements of escaped slaves (quilombos) (MOTA and BRAICK, 2002). This is also how the foundation of Lavras, a city in Southern Minas Gerais, occurred.

At the end of the $18^{\text {th }}$ century, as the city developed, and to improve communication with other centers, a branch of the Estrada de Ferro Oeste de Minas, which later became RFFSA - Rede Ferroviária Federal S/A, was implemented into the city. After the train station was built, Dr. José Esteves Square was designed, also known as Train Station Square, whose story and origins are closely related to the events arising from this railroad. The appearance of this municipal garden differs from most Brazilian public squares built during the $18^{\text {th }}$ and $19^{\text {th }}$ centuries, which would usually appear in front of churches (MARX, 1980).

In this context, this study aimed at analyzing the historic, cultural and landscape facts that marked the creation and development of Dr. José Esteves Square around a train station, in addition to running a diagnosis of its current situation.

\section{METHODOLOGY}

The study focused on the period between 1721 (settlement of the municipality of Lavras) and 2016. A historic, cultural and landscape analysis of Dr. José Esteves Square was carried out, based on morphologic information on how the space was occupied, and on social representations found therein. Qualitative methods to carry out this research were used, so as to contextualize the assessed universe.

Field research with previously scheduled visitations and interviews with people who lived in the area in different decades were performed in order to collect the desirable data. Such interviewees were identified and suggested by people who frequently attended the public square, as well as residents of the area or former workers from the train station and railroad. The key questions comprehend the following: "Did you use to spend time at the public square? Describe some pros and cons on the usage of the space"; "What were the changes at Dr. José Esteves Square since its foundation?" "What usage/functions has the public square had?"; "What is the importance of Dr. José Esteves Square for the citizens or city visitors?"; "Is the public square pleasant for leisure activities to take place?" and "Do you remember any remarkable event that took place at the public square?".
The methodology used to study the historic-cultural evolution involved the theoretic contributions of Delphim (2005), Lassus (1994) and Luginbuhl (2006), which were combined to integrate this research and have been previously used by Alves et al. (2015), Juste and Paiva (2015), and Garcia et al. (2017).

The inventive analysis (LASSUS, 1994) aids in the identification of the physical evolution process and common habits in the place, based on natural, social, and heritage information therefrom. That means to differentiate what would be most appropriate in a specific relationship between the place and its social practices. As for subjective analysis (LUGINBUHL, 2006), aesthetic, phenomenological or symbolic values are brought up. This method is based on the hypothesis that landscapes and their representations have values that are brought upon by the population, artists, or even writers who identify such aesthetic or symbolic aspects in their works-of-art. Therefore, by conceiving the analysis of historical gardens, it is important to consider the peculiar aspects of each garden, causing each one of them to have a particular evolution and find their own solutions (DELPHIM, 2005).

The bibliographical survey was carried out in libraries in the cities of Lavras and São João del-Rei (Minas Gerais) and in public archives; publications on the topic, reports given by foreign travelers, and news from local newspapers. In addition, a photographic survey was carried out as a tool to illustrate the transformations the area suffered throughout time, either by illustrating the facts described in the literature, or revealing events that were only registered as images.

Informal interviews were made upon previous scheduling; we sought to follow a personal logic of narrative construction, with general keywords, motivating free conversations/reports, which contributed with information not yet registered onto documents or images, but that are part of memories of local inhabitants.

Based on photographic records, collected data and field observations, a reconstitution, of the public square was made, using digital techniques with the aid of softwares AutoCAD and CorelDraw. With such information, the history of Dr. José Esteves Square was written in a direct way, considering the timeline of its evolution.

\section{RESULTS AND DISCUSSION}

The "Arraial de Sant'Ana de Lavras do Funil", as Lavras was once known, was founded in 1729. The most important economical natural resource found in the municipality was gold, which could be found spread almost everywhere and on riverbanks, besides good quality clay, limestone and magmatic rocks (SANTOS, 1983). The city was an important point on the old route of Estrada Real (Royal Road), used as a station where bandeirantes and miners from Vila Rica - currently Ouro Preto - would replenish their supplies, and as a place to pass by River Grande, which had its crossing by animals and people authorized in 1701, upon the payment of toll (SALGADO, 2009). 
After undergoing mining activities, the Arraial de Lavras do Funil became an area for agriculture and cattle breeding (NÉMETH-TORRES, 2012), allowing the implementation of a branch from the railroad Estrada de Ferro Oeste de Minas (EFOM), which would be responsible for transporting passengers and products arising from agriculture and industries.

\section{The Train Station of Lavras city}

Decree n. 9811, of November 26 ${ }^{\text {th }}, 1889$, set forth the construction of the first track connecting Lavras city to a railroad: a 9,0 km-long trail that would link Ribeirão Vermelho city (Minas Gerais) to Lavras. Therefore, it was necessary to build a bridge over Rio Grande, which started in 1892 and ended in 1894.

Years before such work, in 1822, a traveler named Augusto de Saint-Hilaire, foreseeing the potential benefits that a river such as Rio Grande would bring to the region, wrote:
"Someday, other rivers, Rio Doce, Jequitinhonha and Rio Grande, shall offer the most useful means of transportation to the province of Minas, which is watered by an astounding multitude of rivers and springs". SaintHilaire (1938, p. 85).

One of the hypotheses registered by historians for the construction of a train station in Lavras, was based on the fact that constant floods would hamper or prevent the traffic of trains in the city of Ribeirão Vermelho (LUZ, 2014b). Therefore, a simple building was built for the Train Station of Lavras, which was inaugurated on April $1^{\text {st }}, 1895$. Later on, in 1914, an engineer named Américo Paiva (COIMBRA, 2009) designed a more elaborated architectonic project, which was not found as a hardcopy; there is only a photo (Figure 1) of the building itself. In later years, the station underwent two big remodeling processes.

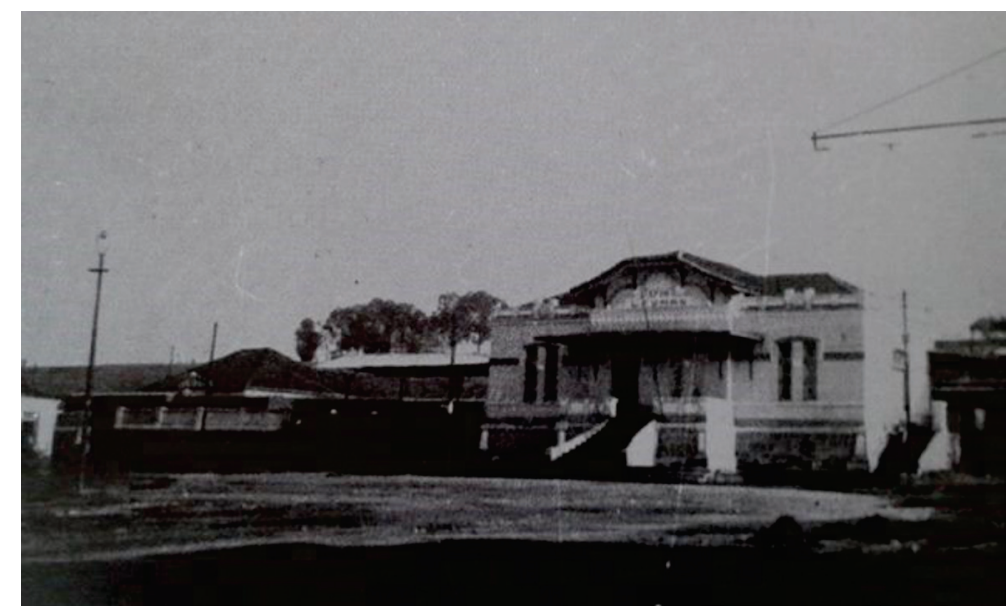

Figure 1. The second building for the Train Station of Lavras, concluded in 1914. Unknown author. Source: COIMBRA (2009).

The Train Station Square and its early years

In the 1910's, the Train Station Square did not exist yet, as evidenced by its first photo registration (Figure 2). It is possible to see the tram, which would connect the station to the city center, and dirt roads.

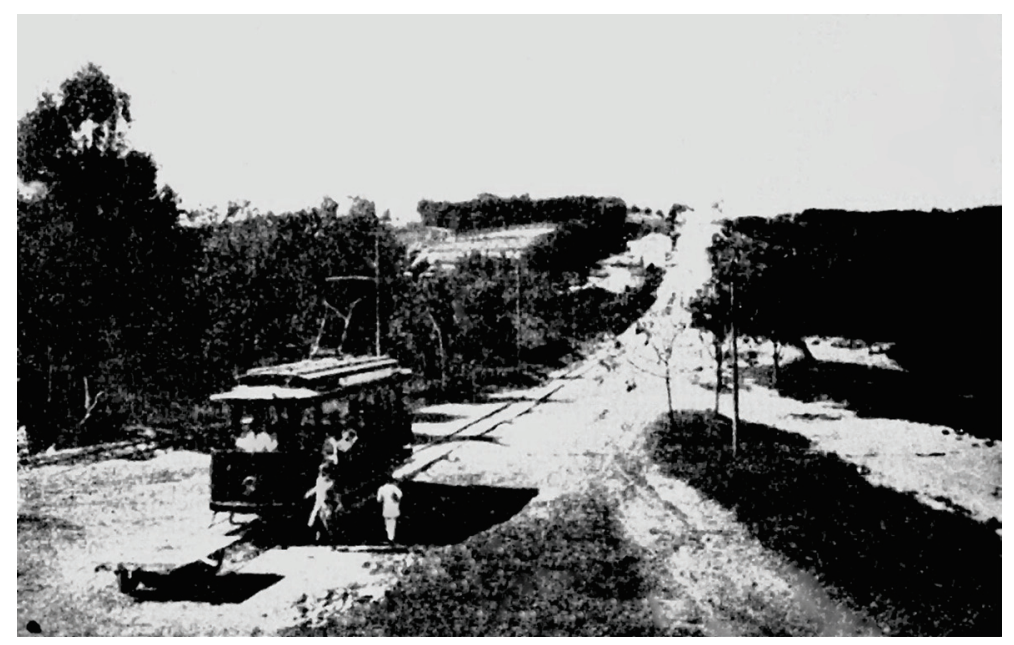

Figure 2. Previous location of Dr. José Esteves Square. Unknown author. Source: Bi Moreira Museum. 
A tram service had been inaugurated in 1914 and it was responsible for connecting the city center to the unpopulated lower area of the city, where the Train Station had been built.

In 1929, as the number of passengers increased and the Train Station building would also be used as lodging, mostly for telegraphists, a remodeling process was necessary to amplify the space, which was made by RMV - Rede Mineira de Viação (a company founded after EFOM was liquidated, and that took over the railroad transportation in Lavras), increasing the proportions of the Train Station (COIMBRA, 2009), under an eclectic style (Figure 3).

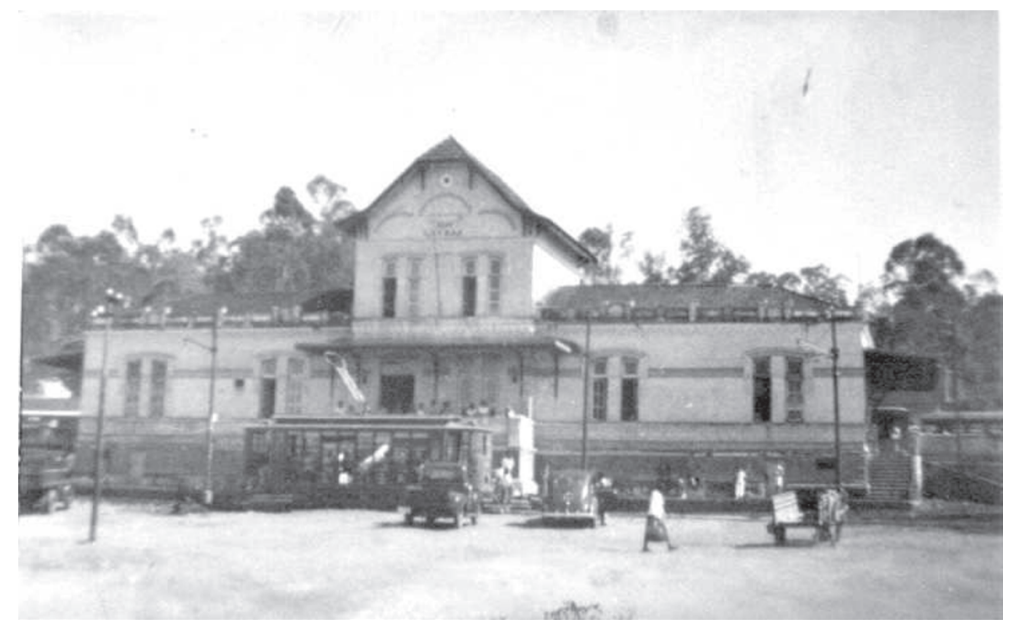

Figure 3. The Train Station of Lavras after remodeling, in the 1930's. Unknown author. Source: Renato Libeck's personal archives.

It is worth mentioning that, differently from other train stations, there was no clock in that buiding. A clock was installed in another building, the city's Tram Station, where people would buy tickets (Figure 4).

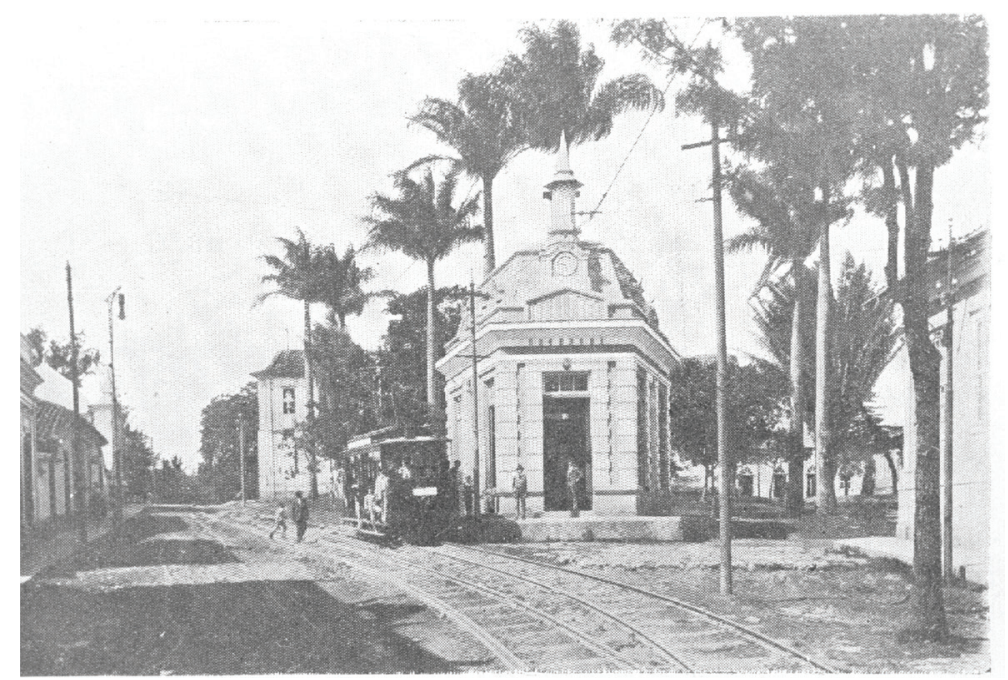

Figure 4. The Tram Station, located at Barão de Lavras Square, with its famous clock (1911). Unknown author: Source: Bi Moreira Museum.

Along with the Tram Station, there was a small garden named Barão de Lavras, which, despite being located close to Igreja do Rosário (Rosary Church), belonged to the Station. Its building was brought down in 1942, even though it would be the workplace to tailors (VILELA, 2015), and houses were built thereon. However, in 1942, the garden did not exist anymore; the area was renamed as
Cincinato de Pádua Street, under Law nº.12, of December $30^{\text {th }}, 1939^{(4)}$.

Several commercial establishments started to develop around the Train Station Square, such as hostels, hotels, as well as some factories, since it was a place with great flow of people and goods and due to the great economic potential the area offered. 
In the beginning of the 1930 's, the situation in the area was very similar to 1910 , with no major changes. There were no recorded attempts to urbanize the area, except for the presence of street lighting with public light poles. The roads remained unpaved. Nevertheless, it was possible to see some new residences in the surroundings (Figure 5).

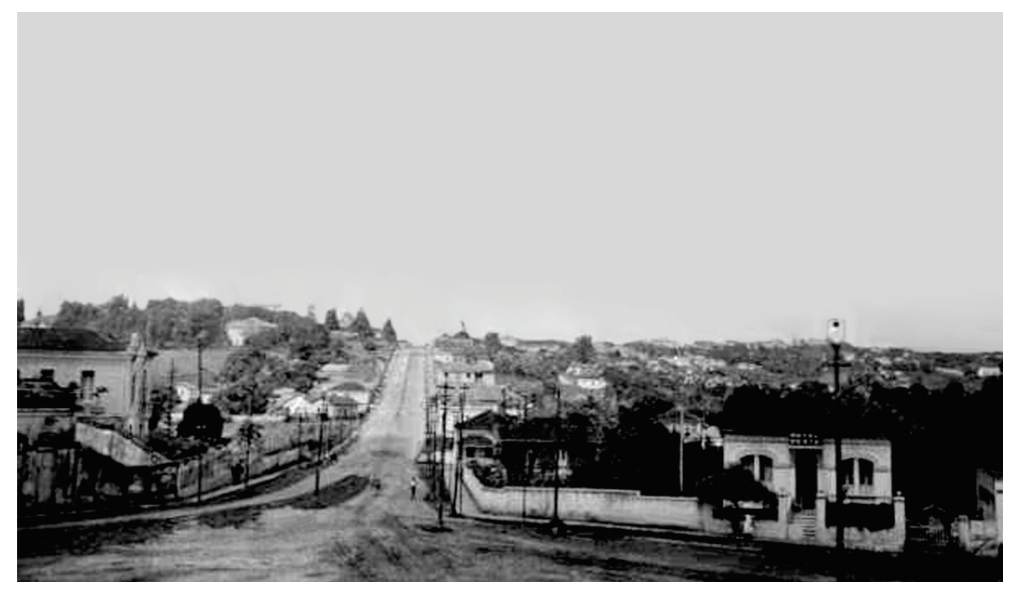

Figure 5. The area of the Train Station Square in the 1930's and Avenida XX de Julho (currently Avenida Pedro Sales), still unpaved. Unknown author. Source: Bi Moreira Museum.

The railroad station was not settled on the central part of the city; it was rather installed in the lower region thereof. From such settlement, this part of town became a strong commercial spot and railroad workers started populating the area, thus becoming the first visitors of the future Train Station Square.

From another point of view, an image from 1931 shows the area used to be a simple parking lot (Figure 6).

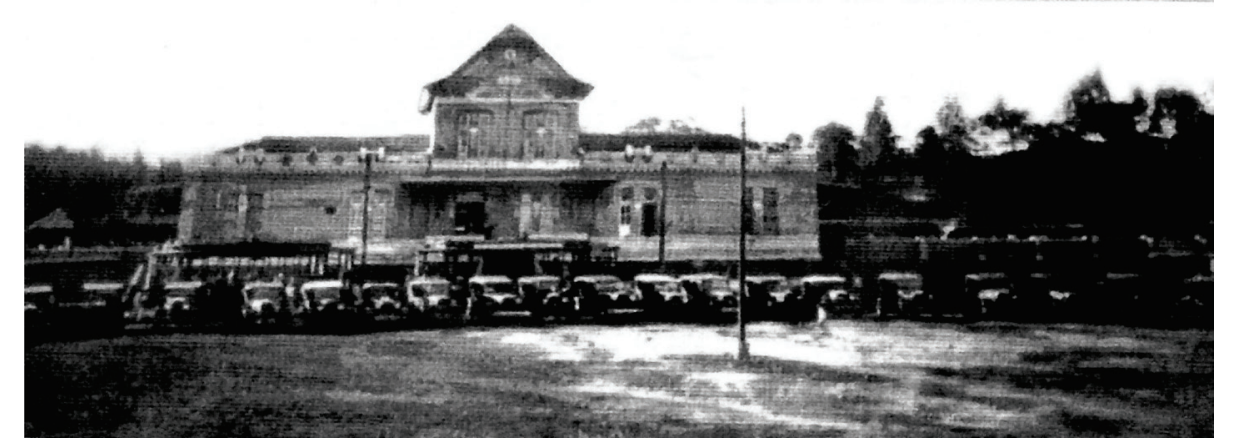

Figure 6. The Train Station of Lavras. Photo from the day that President Getúlio Vargas and his group visited the town, in 1931. Unknown author. Source: Coimbra (2009).

The Train Station of Lavras and its future garden were marked by several historical events for the city and region, such as the first time the town received the visit of a President, Getúlio Vargas, in 1931 (OLIVEIRA, 1980; 81 ANOS, 2012).

Another remarkable event at the Train Station of Lavras happened on March 21 $1^{\text {st }}$, 1934, and relates to the Constitutionalist Revolution ${ }^{(5)}$. Soldiers from Belo Horizonte (capital of the State of Minas Gerais) arrived with their families at the Train Station of Lavras, in order to integrate and form the $8^{\text {th }} \mathrm{BCM}$ - Troop of Mineiro
Hunters, currently the $8^{\text {th }}$ Troop of Military Police of the State of Minas Gerais (80 ANOS, 2014).

At that time, there were no gardens, flowerbeds or furniture that would characterize the area as a public square, but the place was commonly known as "Train Station Square" space. Dr. José Esteves was a doctor that used to work and live in the Train Station Square area before its creation. Due to his services to Lavras, his name was chosen to denominate the area commonly known as "Train Station Square". Thus, under local Law $n^{\text {o }} 12$, of December $12^{\text {th }}, 1939$, the area received an official name: Dr. José Esteves Square.

\footnotetext{
${ }^{(5)}$ A manifestation of dissatisfaction, performed by paulistas (residents of São Paulo) towards the 1930's Revolution. The 1932's Constitutionalist Revolution aimed at convincing the Temporary Government of Brazil (presided by Getúlio Vargas) of the need to put an end to an arbitrary regimen the country had been facing (MOREIRA, 2016).
} 
Public square creation and its original landscape design

Despite being known as a public square and having a name, only between 1947 and 1951 the space that measures $27,400 \mathrm{~m}^{2}$ become urbanized, receiving new structures, landscape furniture and planting. The date of inauguration, as well as the identity of the person who prepared the landscape design, is uncertain but, the photo record the inauguration, shows people gathering in front of the Station for the ceremony. The photo also reveals part of the landscape design, that included cypress trees (Cupressus sp.,), sago palms (Cycas revoluta), foraging (species could not be identified) and young tree species, with geometrical flower beds and a circular bed at the center of the public square (Figure 7). Native and foreign species were used jointly, without a defined style.

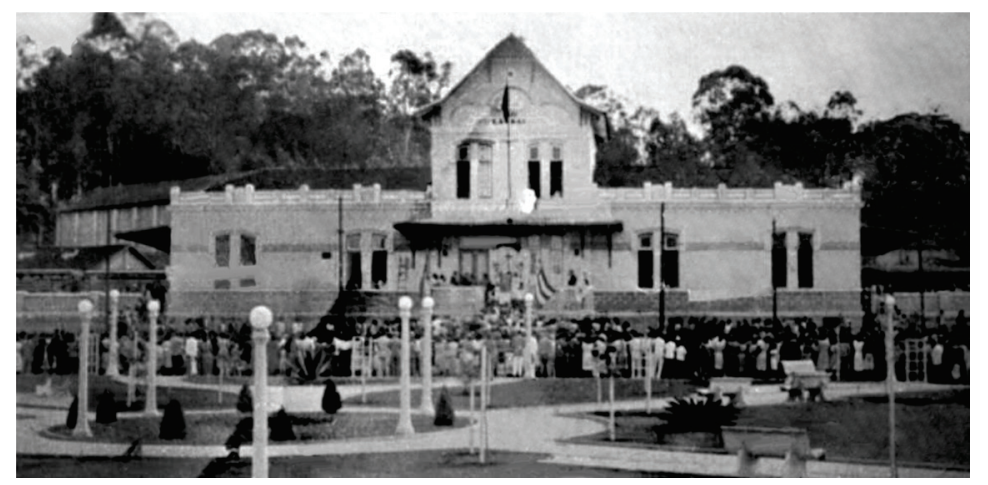

Figure 7. Inauguration ceremony of the Train Station Square in Lavras, most likely in 1951. Unknown author. Source: Renato Libeck's personal archives.

It is also possible to observe benches made out of concrete and the lamp posts fueled by gas (LUZ, 2014a). These type of posts were also found in public squares from other cities at that time. Its outline had mostly straight lines, though there are asymmetries in some points.

As mentioned before, the original public square's landscape design was not found. The lack of registration does not allow this research to infer whether if it was lost or if the design never existed. In order to better understand and discuss the space, a redrawn was made by the authors, based on photographic records, collected data and field observations made by the authors in 2017. The redrawn is shown in the image below (Figure 8).

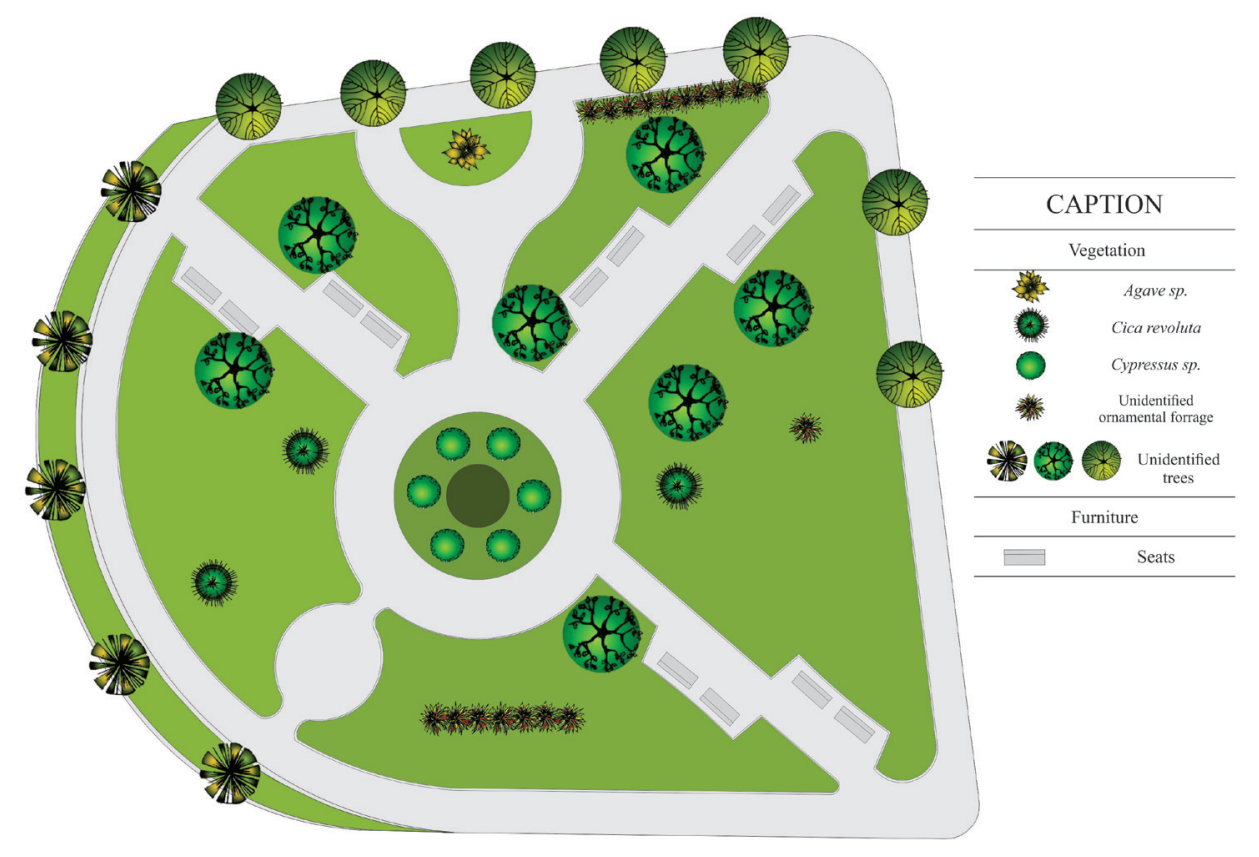

Figure 8. Reconstitution of the project for Dr. José Esteves Square at the time of inauguration. Author: Iracema C. A. Luz. 


\section{Site Context}

Dr. José Esteves Square was built in a square in front of the Train Station of Lavras (Figure 9). Located in an area that belonged to RMV (Rede Mineira de Viação) at that time, the public square was surrounded by stockrooms, woodshops, company's offices, engineers' houses, the Train Station bridge, the Train Station itself, railroad shops, among other buildings that belonged to the company (DELPHIM, 2014).

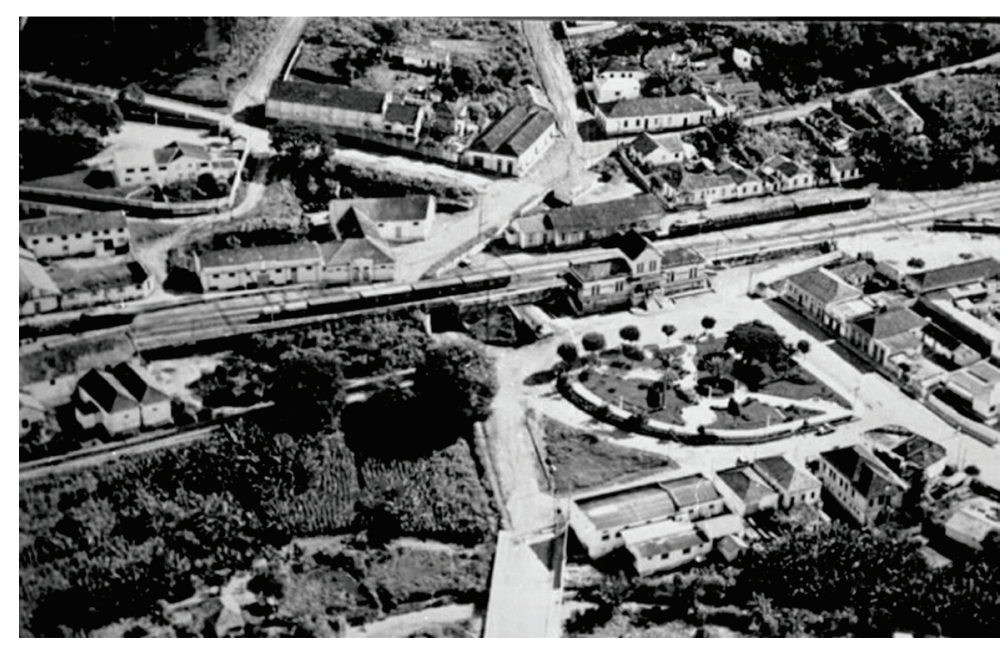

Figure 9. Aerial image of Dr. José Esteves Square and its whereabouts in the 1960's. Unknown author. Source: Renato Libeck's personal archives.

Thus, the creation of this public square occurred differently from what used to happen to most Brazilian public squares at that time, which would usually be built near churches (CALDEIRA, 2010). Another important fact is the opposition to public squares from colonial times. They used to be spontaneously created in towns (CALDEIRA, 2010). In Brazil, building such areas in front of train stations represented the accomplishment of a new concept of public gardens. The creation of public squares in front of railroads was not exclusive to Lavras: in several Brazilian towns, where railroads were implemented between the end of the $19^{\text {th }}$ century and the beginning of the $20^{\text {th }}$ century, gardens were created immediately, or some years after the construction of train stations, and several were named "Train Station Square". Such name was changed in many towns (BARBOSA, 2015; MUSEU DE ARTES E OFÍCIOS, 2015), but the term "Train Station Square" remains in the population's memory.

As for landscape impressions offered to visitors who used the train stations as a reference to the places they arrived at, Capistrano de Abreu, a Brazilian writer and historian, reported:

Last week, I met a group that would travel along the part of Minas Gerais covered by E. F. Oeste de Minas that they had not yet visited (...) There were lunches, dinners, speeches, and the national anthem. We passed by Turvo, Lavras, Itapecerica, Divinópolis and Belo Horizonte.
There were no vehicles, except in Lavras, where there was a tram line, and in so many cities, I could only appreciate what was visible from the station or from the train (RODRIGUES, 1977, our highlight).

Therefore, most times, the only impression travelers would have of the towns they passed through was the one offered by the whereabouts of the train station. Thus, creating gardens around such places was highly important.

\section{The evolution of Dr. José Esteves Square}

In 1969, the Train Station building underwent its last renovation, which was rather drastic and entirely modified its style. That year marked the city's centennial and modernism was the architectonic style in vogue at the time, for it meant progress (ESTAÇÃO, 1969b). Consequently, part of the society wanted to exterminate whatever was considered obsolete (ESTAÇÃO, 1969a) and that included the characteristics of the old Train Station of Lavras, which did not fit to the modern architecture movement environment. Thus, the old building was demolished, and a new one was brought up, with straight lines and no equivalents to the old one.

In order to follow the transformations made to the Train Station and to ensure the public square could "match the building VFCO(6) constructed there" (PRAÇA, 1969), the local government also renovated the gardens (PRAÇA, 1969). The gardens outline were not modified though (Figure 10).

${ }^{(6)}$ VFCO - Viação Férrea Centro-Oeste was created in 1965, after the merger of Rede Mineira de Viação (RMV) and Estradas de Ferro Bahia a Minas (EFBM) and Estradas de Ferro Goiás (EFG) (BUZELIN and SETTI, 2001). 


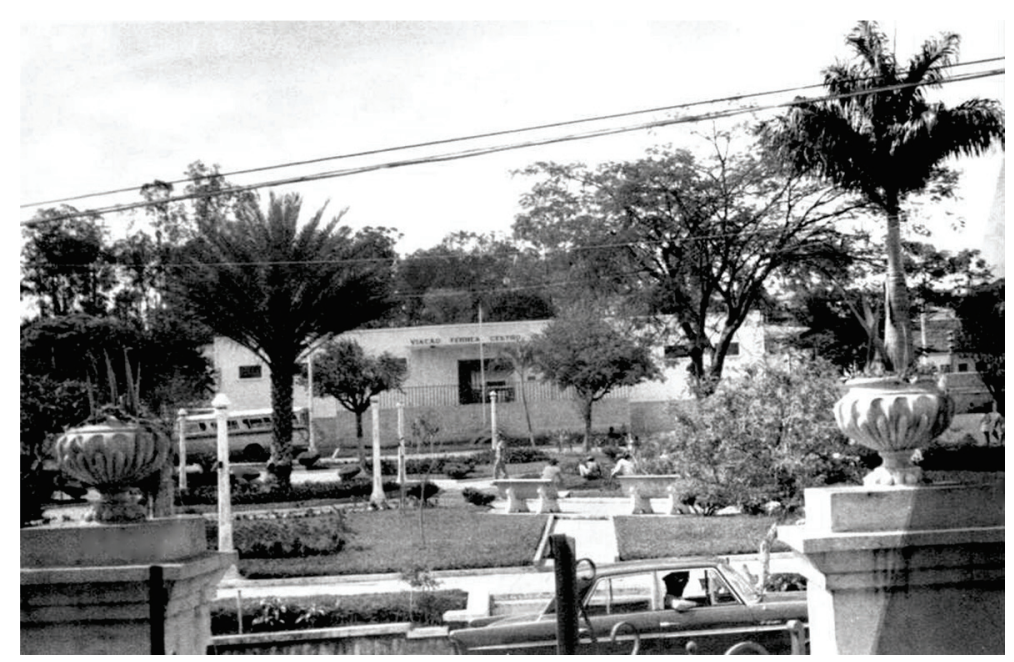

Figure 10. The Train Station in 1969.

Unknown author. Source: Renato Libeck's personal archives.

Despite such improvements, the public square would not always be properly cared for; the public square maintenance would frequently be done by residents (DELPHIM, 2014). Because of the dedication offered by the population, mainly railroad workers who resided nearby the public square during the 1970's and further years, the public square became a reference for the city gardens.

At that time, the west area of the public square had no gardens, and the natural grass was very dense. Such space used to be a parking lot for trucks from a transportation company that had its headquarters office in that area. In 1977, this area was renovated and added to the public square (NOSSOS, 1970; PRAÇAS, 1972).

In May 1997, a Maria-Fumaça ${ }^{(7)}$, manufactured in the United States, by Baldwin, Eddystone in 1920 (POUCO, 2001), was placed in Dr. José Esteves Square, after due renovation (MARIA, 1997). This locomotive became the local symbol, not only for its beauty, but also for its meaning, transforming the local landscape.

The last registration of a landscape intervention to the public square dates to 2002, when the public square received new structures, such as a pergola and a police station, in addition to modifications to the vegetation, with the inclusion of crape myrtles (Lagerstroemia indica) and yellow alders (Turnera ulmifolia) to their beds, for instance. These were fairly rustic species, chosen for their ease of maintenance and commonly used in the renovation and construction of gardens made at that time.

\section{Current structure and composition}

Currently, after years of glamour, the public square lacks maintenance and revitalization. There are too few waste bins and lamp posts, and the others that remaining are mostly broken.

Benches are old, damaged, and made of a material that is not used anymore, which does little for the aesthetics of the place. Some of them come from renovations to other public squares in town (LUZ, 2014c).

As time passed, the public square was neither a place for leisure, nor the stage for big cultural events, mainly due to the decay or inexistence of railroad transportation of passengers and cargos, which were gradually deactivated from 1996 on. Thus, Train Stations became obsolete and that reflected on the functions and use of areas around such structures.

This low conservation can be associated with its architecture, with characteristics that disagree to those of the time in which the public square was in its peak, losing the construction of its symbolism. Currently, the building remains unused. The view to its façade is blocked by plant species and different urban equipment (bus stop), which were not part of the original concept (Figure 11).

(7) A locomotive fueled by a steam engine that received such a name, due to the amount of smoke it emitted from its chimneys. 


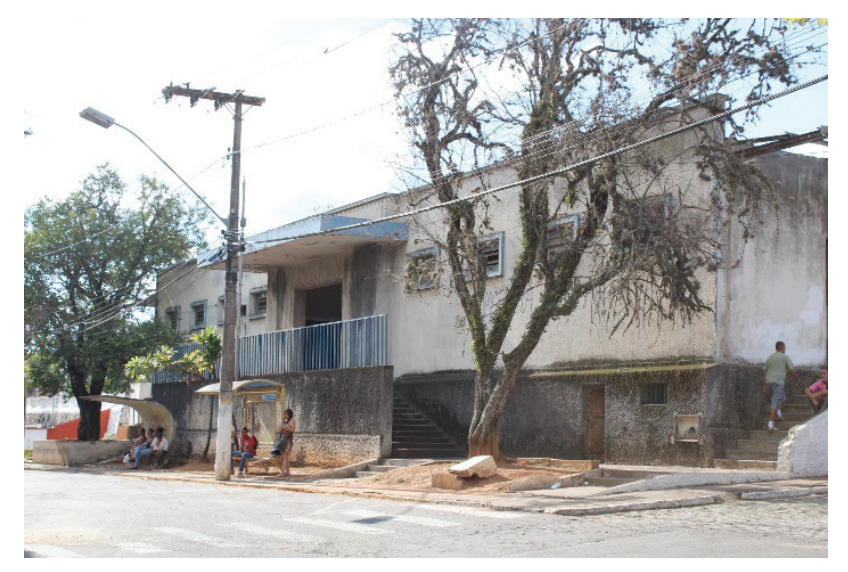

Figure 11. Current façade of the Train Station of Lavras. Author: Iracema C. A. Luz.

The old buildings around the Train Station, once used as shops and offices, are also being ruined, either by abandonment or bad weather effects.

Despite these conditions, the public square still resists, but there have been several alterations to its plant composition (Figure 12), as many plant species have been introduced without proper landscape planning, some of them derived from spontaneous seeding. Examples are: date palm (Phoenix dactilifera) (Figure 13), croton (Codiaeum variegatum) (Figure 14), weeping bottlebrush (Callistemon viminalis), flamboyant (Delonix regia), "sibipiruna" (Caesalpinia peltophoroides) (Figure 15), trumpet tree (Tabebuia spp.), "oiti" (Licania tomentosa), areca palm (Dypsis lutescens) (Figure 16), weeping willow (Salix x pendulina) (Figure 17), imperial palm (Roystonea olearacea), juçara palm (Euterpe edulis), Puerto Rico royal palm (Roystonea borinquena), rosewood (Tipuana tipu), crape myrtle (Largestroemia indica), lantana (Lantana sp.), Kapok (Ceiba sp.), glory trees (Tibouchina granulosa), ipes (Handroanthus spp.) (Figure 18); all these plants have no relation to the first project of the public square.

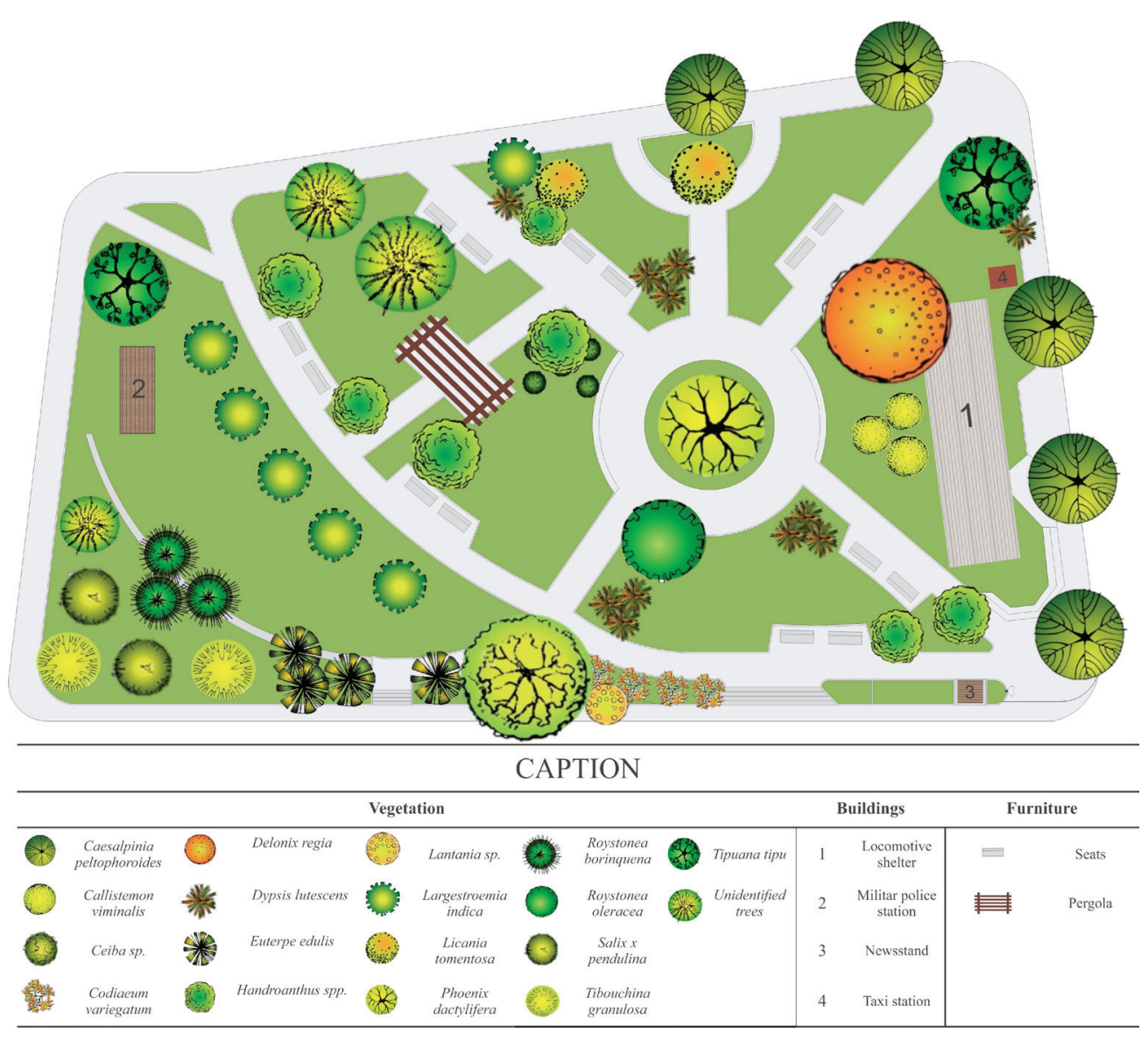

Figure 12. Current situation (2016) of Dr. José Esteves Square. Author: Iracema C. A. Luz. 


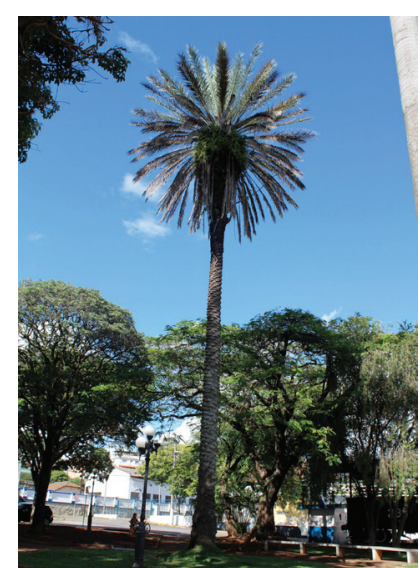

Figure 13

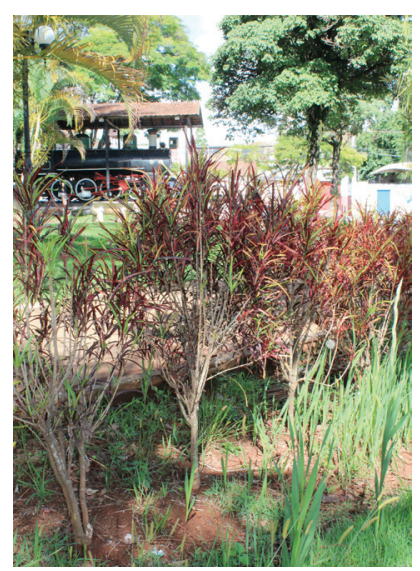

Figure 14

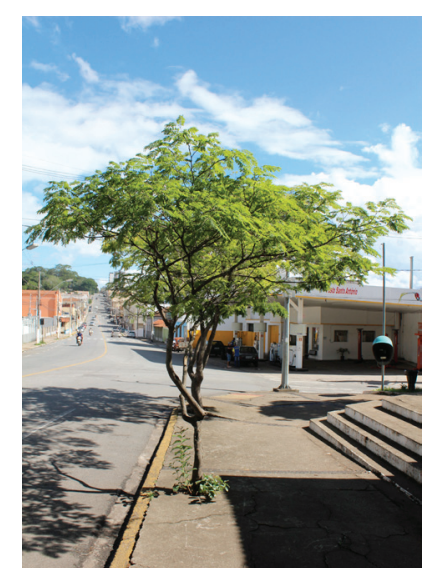

Figure 15

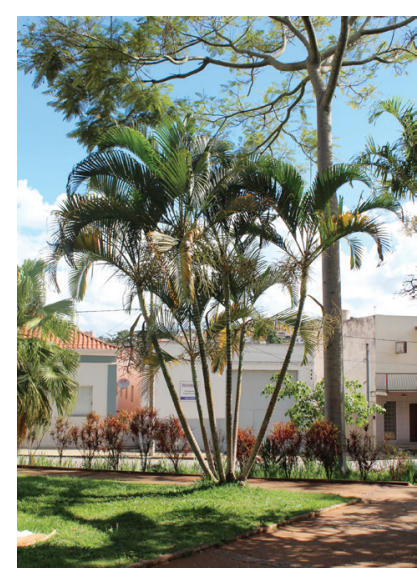

Figure 16

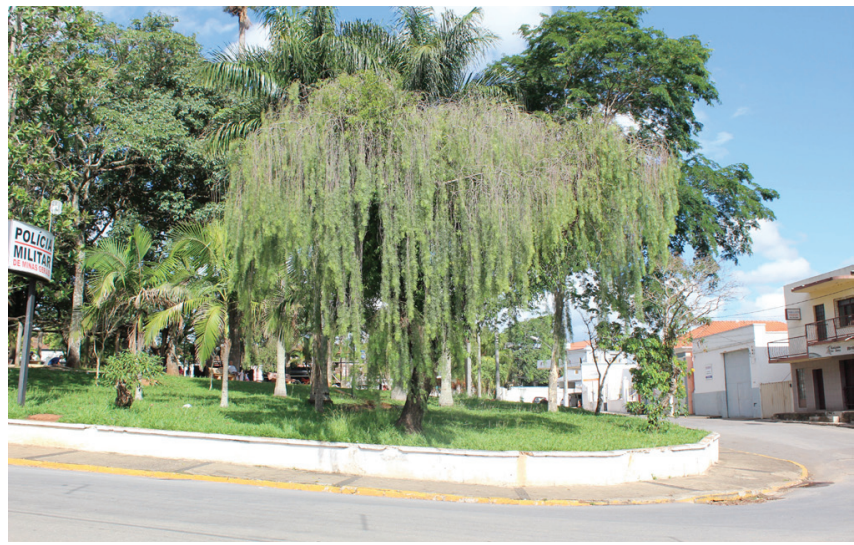

Figure 17

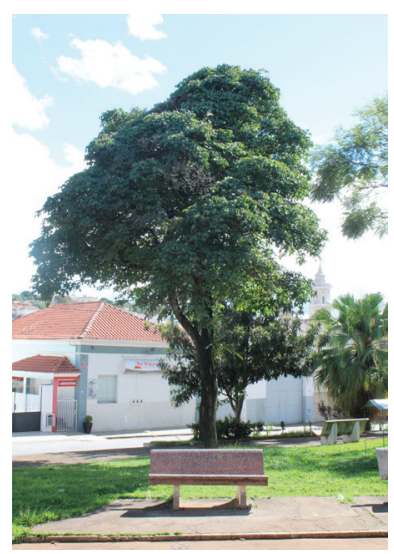

Figure 18
These were some of the factors that influenced the landscape changes in the public square throughout time, when compared to the plants allocated there in the first settlement and to those observed in the following years, due to the lack of concern to maintaining the same species. Another factor that contributed to such a change was the insertion of certain constructions, such as the shelter for the steam locomotive, a newsstand, a taxi stand and a police station.

Several users see the public square as an uninteresting place, which could receive some improvements (BISSOLI, 2006). Thus, the entire area needs to be renewed, not only to restore some of the original characteristics, but also the people's pleasure in attending the place, since the public square was a stage for several important facts in the city of Lavras.

\section{CONCLUSIONS}

With the research, it was possible to make a reconstruction of how the rise of the public square occurred, besides its evolution.

The public square was created with the purpose of decorating the space in front of the Railroad Station of Lavras, marking a moment when these spaces started to be built in a planned manner.

Currently, both original gardens and surroundings are disposed. The insertion over the time of vegetation and public furniture, both different from the original design, contributed to the public square mischaracterization. Associated to this, the entire Railroad Station area garden is in decline.

The first factor that caused such decay was the demolition of the old station, a highly estimated architectonic workof-art, which was destroyed in the name of "progress" and "modernity". Furthermore, the deactivation of railroad transportation services also caused the buildings obsolescence, which interfered with the landscape quality of the public square.

Since it is a place of historical importance, it is necessary beyond to restoring and revitalizing both public square and its surroundings, bringing back the original characteristics of the past and, associate them with the present expressing the original meanings the place had for society.

\section{ACKNOWLEDGMENTS}

The authors are thankful to FAPEMIG and CNPQ for the financial support.

\section{AUTHORS CONTRIBUTIONS}

I.C.A.L.: performed the research, collected the information and interviews, data analyzed, took the photos, and wrote the first draft of the manuscript. P.D.O.P: development of the idea of the research project, adaptation 
of the methodology, performed part of the research, critical reading and editing of the manuscript. S.F.N.S.C.A.: helped in development of the idea of this research project, helped in adaptation of the methodology and performed a critical reading of the manuscript.

\section{REFERENCES}

ALVES, S.F.N.S.C.; GARCIA, C.S.G.; PAIVA, P.D.O. Transformações físicas e apropriações sociais da Praça Tiradentes em Ouro Preto-MG. Ornamental Horticulture, v.21, n.2, p. 209-220, 2015. DOI: http:// dx.doi.org/10.14295/aohl.v21i2.670

ANDRÉ, P. A praça XV de novembro como paisagem cultural da cidade do Rio de Janeiro. In Materialização da Paisagem através das Manifestações Sócio-Culturais. Rio de Janeiro: Universidade Federal do Rio de Janeiro, 2008. p.36-47, vol. 1 .

BARBOSA, L.T. Praça da Estação: memórias e sociabilidade em Juiz de Fora (MG). Ponto Urbe. São Paul, 2015. 6 p.

BISSOLI, M.A. Abandono da Praça Dr. José Esteves preocupa moradores. Tribuna de Lavras, Lavras, n. 2388, p.3, 12 jul. 2006.

BULZELIN, J.E.; SETTI, J.B. Ferrovia CentroAtlântica: uma ferrovia e suas raízes. Memória do Trem, Rio de Janeiro, 160p, 2001.

CARTA DE FLORENÇA: carta dos jardins históricos. Icomos, 1981. Cadernos de Sociomuseologia, n.15, p.201-208, 1999.

CARTA DE JUIZ DE FORA: carta dos jardins históricos brasileiros. Juiz de Fora: IPHAN, 2010. p.13.

CALDEIRA, J.M. A praça colonial brasileira. Revista Universitas: Arquitetura e Comunicação Social, v.7, n.1, p.19-39, 2010. DOI: http://dx.doi.org/10.5102/uc.v7i1.1113

COIMBRA, R.R. Uma viagem pelos trilhos da Centro Oeste: 120 anos de história ferroviária. São Lourenço: Novo Mundo, 2009.

DELPHIM, C.F.M. Intervenção em jardins históricos: manual. Brasília: IPHAN, 2005. 152p.

ESTAÇÃO da V.F.C.O. sofrerá reformas. Tribuna de Lavras, Lavras, n.68, p.2, 5 jan. 1969a.

ESTAÇÃO da V.F.C.O. aqui terá nova fachada. Tribuna de Lavras, Lavras, 14 set. 1969 b.

GARCIA, C.S.G.; PAIVA, P.D.O.; ALVES, S.F.N.S.C.;
SALGADO, M.C.R. Transformations in the gardens and landscapes of the historical Traituba's farm. Ornamental Horticulture, v.23, n.3, p.45-57, 2017. DOI: http://dx.doi. org/10.14295/oh.v23i1.953

HÁ 80 ANOS chegavam a Lavras, os homens do $8^{\circ}$ BCM. Jornal de Lavras, Lavras, 20 mar. 2014. Disponível em: $<$ http://www.jornaldelavras.com.br/ index. php? $\mathrm{p}=10 \& \mathrm{tc}=4 \& \mathrm{c}=8185>$. Acesso em: 6 de agosto de 2013.

HÁ 81 ANOS Lavras recebia a visita de um ilustre Presidente da República. Jornal de Lavras, Lavras, 26 fev. 2012. Disponível em: <http://www. jornaldelavras. com.br/index.php? $\mathrm{p}=10 \& \mathrm{tc}=4 \& \mathrm{c}=3802>$. Acesso em: 20 de março de 2014.

JUSTE, L.C.; PAIVA, P.D.O. Resgate histórico da praça da Basílica de Bom Jesus de Matosinhos em Congonhas, Minas Gerais. Ornamental Horticulture, v.21, n.1, p.6376, 2015. DOI: 10.14295/rbho.v21i1.777

LASSUS, B. L'obligation de I'inventio: du paysage aux ambiances successives. BERQUE (Dir.). Cinq propositions pour unethéorie du paysage. Paris: Champ Vallon, 1994, p.81-106.

LUGINBUHL, Y. Paysage et identification, qualification et objectifs de qualités. Paysage et développement durable: les enjeux de la convention européenne du paysage. Strasbourg: I'Europe, 2006, p.107-125.

LUZ, I.C.A. Entrevista com Ângelo Alberto Moura Delphim. Lavras - MG. Fevereiro de 2014a.

LUZ, I.C.A. Entrevista com Bruno Nascimento Campos. Lavras - MG. Fevereiro de 2014b.

LUZ, I.C.A. Entrevista com João Batista Soares. Lavras - MG. Março de 2014c.

MAGALHÃES, C.M. Na rota dos caminhos da estrada real e dos tropeiros. Cadernos de Pesquisa do CDHIS, v.1, n.36/37, p.111-117, 2007.

MARIA Fumaça está na praça. Tribuna de Lavras, Lavras, n.1612, p.1, 31 mai. 1997.

MARX, M. Cidade brasileira. São Paulo: Melhoramentos, 1980.151 p.

MOREIRA, R.L. Fatos e imagens: artigos ilustrados de fatos e conjunturas do Brasil. Fundação Getúlio Vargas. Disponível em: <http:/cpdoc.fgv.br/producao/dossies/ FatosImagens/Revolucao1932>. Acesso em 24 de outubro de 2016.

MORGAN, L. Out of time: temporality in landscape 
history: Introduction. Studies in the History of Gardens \& Designed Landscapes, v. 36, n.4, p.221-224, 2016.

DOI: http://dx.doi.org/10.1080/14601176.2016.11619 25

MOTA, M.B.; BRAICK, P.R. História: das cavernas ao terceiro milênio. São Paulo: Moderna, 2002. 592 p.

MUSEU DE ARTES E OFÍCIOS. O edifício e a praça (Cronologia). Disponível em: < http://www.mao.org.br/ conheca/o-edificio-e-a-praca/ $>$. Acesso em 9 de nov. de 2016.

NEMETH-TORRES, G. De Parnaíba a Lavras do Funil: subsídios para a história das origens de Lavras, 1712-1729. Lavras: Edição do autor, 2012. 28 p.

NOSSOS campos tem mais flores, nossos bosques tem mais vida. Tribuna de Lavras, Lavras, n.167, p.4, 19 jul. 1970 .

OLIVEIRA, H. O dia em que Getúlio chegou. Tribuna de Lavras, Lavras, n.741, p.2, 12 out. 1980.

OLIVEIRA, H. Pelos caminhos de Josepha Campeira. Lavras: [s. n.], 1983. 118 p.

PRAÇA da Estação está sendo melhorada. Tribuna de Lavras, Lavras-MG, 5 de outubro de 1969.
PRAÇAS e jardins. Tribuna de Lavras, Lavras, n.320, p.1, 24 set. 1972 .

RODRIGUES, J. H. (Org.). Correspondência de Capistrano de Abreu. Rio de Janeiro: [s. n.], 1977. v. 1.

SAINT-HILAIRE, A. Viagem pelas províncias do Rio de Janeiro e Minas Gerais. São Paulo: Nacional, 1938. $378 \mathrm{p}$.

SALGADO, A. Lavras foi incluída no Projeto Turístico da Estrada Real. Tribuna de Lavras, Lavras, n.2654, p.2, 11 abr. 2009.

SANTOS, C.M. História de Lavras. Tribuna de Lavras, Lavras-MG, 17 de set. de 1983.

SHUTTERSTOCK. Set of treetop symbols, for architectural or landscape design. Altura: 1946 pixels. Largura: 42155 pixels. 579 KB. Formato JPG. Disponível em: https://www.shutterstock.com/imagevector/set-treetop-symbols-architectural-landscapedesign-317687549. Acesso em: 5 de dez. De 2017.

UM POUCO de história. Tribuna de Lavras, Lavras, n.1847, p.1, 21 de mar. de 2001.

VILELA, M. S. A formação histórica dos Campos de Santana das Lavras do Funil. Lavras: Indi, 2007. 449 p. 